\title{
Clinical Outcomes of Drug-related Problems in Saudi Arabia: Patients' and Healthcare Providers' Perspective
}

\author{
Yousef Ahmed Alomi*1, Awatif Saad Al-Shaibani², Ghadeer Alfaisal' ${ }^{2}$, Njood Mohmmed Alasmi² \\ ${ }^{1}$ The Past General Manager of General Administration of Pharmaceutical Care and Past Head, National Clinical pharmacy, \\ pharmacy practice and Pharmacy R and D Administration, Ministry of Health, Riyadh, KSA. \\ ${ }^{2}$ Clinical Pharmacy Staff, Ministry of Health, P.O.BOX 100, Riyadh 11392, Riyadh, KSA.
}

Received: 23 February 2018; Accepted: 11 May 2018

*Correspondence to:

Dr. Yousef Ahmed Alomi, The Past General Manager of General Administration of Pharmaceutical Care, The Past Head, National Clinical Pharmacy, and Pharmacy Practice, The Past Head, Pharmacy $R$ and D Administration Ministry of Health, P.O.BOX 100, Riyadh 11392, Riyadh, SAUDI ARABIA. Email:yalomi@gmail.com

Copyright: (C) the author(s),publisher and licensee Indian Academy of Pharmacists. This is an open-access article distributed under the terms of the Creative Commons Attribution Non-Commercial License, which permits unrestricted non-commercial use, distribution, and reproduction in any medium, provided the original work is properly cited.

\begin{abstract}
Purpose: To explore the patients and healthcare providers' attitudes and perceptions on clinical outcomes drug-related problems in Saudi Arabia. Methods: It is a 4-months cross-sectional survey of drug-related problem information in Saudi Arabia. The study consisted of two-part a demographic data. The second part contained the questions about the frequent occurrence of drug-related problems, the type of medication-induced those problems, and the drug-related problem clinical consequences and outcomes. American Society of HealthSystem Pharmacist definitions of drug-related problems used. The 5-point Likert response scale system used. The survey distributed through social media. The questionnaire made of an electronic format, and it analyzed through survey monkey system. Results: The total responders were two hundred and one; the Saudi nationality was $188(93.5 \%)$, and non-Saudi was $13(6.5 \%)$ patient. The gender distribution was female $180(89.6 \%)$, and the male was 21 (10.4\%). The majority of them in age (18-44) 88\% and located in Riyadh region $84(41.8 \%)$ and Asir region 59 (29.4\%). Of those $44(22.1 \%)$ were healthcare providers. The responders showed a high percentage of drug-related problem consequences and outcomes; drug-related problem lead to pharmacy visit was 59 (29.5\%), additional tests were $47(24.35 \%)$, ambulatory care clinic visit was $76(38.4 \%)$, and an emergency visit was $43(21.4 \%)$. The hospital admission was 46 (23.1\%), general surgery 24 (11.9\%), critical care admission was $24(12.1 \%)$, and drug-induced death was $48(24.12 \%)$. The most frequent drug-related problems occurred with the patient last year at least once; it was drug noncompliance 142 (71.4\%), indications without medication 100 (50\%), and adverse medication events 80 (40\%). The most type of medicines induced the problems were Antibiotics, the drugs for pain, and dermatology drugs. Conclusion: Clinical outcome of drug-related problems occurred was potential. Clinical pharmacy services with emphasis to a drug-related program of antibiotics, painkiller dermatology medications are necessary. Moreover, to patient counseling program in health institutions and public awareness of medications is required in Saudi Arabia.
\end{abstract}

Key words: Clinical outcomes, Drug-related problems, Patients, Healthcare providers, Perspective, Saudi Arabia.

\section{INTRODUCTION}

The pharmacist provides pharmaceutical care on the regular basis that is to the particular best clinical outcome, improve patient quality of life, and prevent drug-related problems. ${ }^{[1]}$ The drug-related problems consisted of eight problems according to American Society of Health-System Pharmacist..$^{[1-2]}$ It included adverse drug reaction, medications errors, a drug without indication, failure to receive medication, indicators without medications, drug interaction, drug noncompliance, and drug poisoning. Several international and local studies conducted to measure the complications outcomes of those problems. That has included a visit the doctor at ambulatory care clinic or emergency visit, hospital admission, or critical care admission or death. ${ }^{[3-11]}$ Most of the studies done retrospective or perspective with follow up. There's not involved the patient respective and view. The investigator not familiar with studies discussed the clinical outcome of drug-related problems with healthcare professionals and patient perspectives. The objective of the study to explore the extent and the complications of drug-related problems with the healthcare professionals and patient perspective in Kingdom of Saudi Arabia.

\section{METHOD}

It is a 4-months cross-sectional survey of drug-related problem information in Saudi Arabia. The survey consisted of two-part demographic information, and second part consisted of thirteen questions focusing on general knowledge of drug-related problems, their occurrence, and costs. The questions divided into three domains. It included domain 1: Primary or essential information about knowledge and perception of drug-related problems, domain 2: The cost analysis of drug-related problems, domain 3: Clinical outcome of drug-related problems. The questions about the frequent occurrence of drug-related problems, the type of medication-induced those problems, and the drug-related problem clinical consequences and outcomes. American Society of Health-System Pharmacist definitions of drug-related problems used. ${ }^{[1-2,12-13]}$ The 5 -point Likert response scale system used. The questions were open and closed-ended. The survey distributed through social media around Saudi Arabia. The survey distributed through social media by using what's App to almost two thousand public and healthcare professionals overall Kingdom of Saudi Arabia. A messages reminders sent to healthcare professional after two weeks, and additional messages reminders sent to 


\section{Alomi, et al.: Study about drug related problems among Saudi Patients}

healthcare professional after four weeks. The survey made an electronic format, and it analyzed domain three Clinical outcomes of drug-related problems through survey monkey system.

\section{RESULTS}

The total responders were one hundred and one. Of those $155(77.9 \%)$ were patients while $44(22.1 \%)$ were healthcare professionals. Of those, the Saudi nationality was 188 (93.5\%), and non-Saudi was 13 (6.5\%). It is statistically significant in Saudi and non-Saudi between there patient and healthcare professionals. The patients were high in the Saudi nationality while with healthcare professionals higher in the non-Saudi nationality. The gender distribution was female $180(89.6 \%)$, and the male was $21(10.4 \%)$. It is statistically non-significant $(\mathrm{p}<0.5)$ in the in the female and males between Patient and healthcare professionals. The most age was (18-44) represented the eighty-eight percent of responders. There is no statistically significant between all age categories between patient and healthcare professionals expert in the age (18-29) years. The complete most healthcare professionals were pharmacist 34 (65.38\%), and nurses were six (11.54\%) followed by others $5(9.62 \%)$, dentist $4(7.69 \%)$ and $3(5.77 \%)$ physicians. The most responders' qualifications had the Bachelor Degree 137(68.2\%). Followed by High school $30(14.9 \%)$ and Master degree $18(9 \%)$. There is no statistically significant difference in the academic qualifications between patient and healthcare professionals $(\mathrm{p}<0.5)$ as explored in Table 1 . The most type of medications had drug-related problems used was antibiotics, others medications, painkiller medications, and Skin medications. There is statistically differences of type of medications Antidiabetics, Antihypertension, the extent of occurrence and what to do toward the problems (Adverse drug reaction, Medications errors, Drug noncompliance, drug interaction) occurred between patients and healthcare professional $(\mathrm{p}<0.05)$. Others drug-related problems included indication without medications, drug poisoning, medication without indication none statistically differences between patients and healthcare professional $(\mathrm{p}<0.05)$ as explored in Table 2. The responders showed a high percentage of drug-related problem consequences and outcomes; drug-related problem lead to ambulatory care clinic visit was 76 (38.4\%), pharmacy visit was 59 (29.5\%), additional tests were $47(24.35 \%)$, and drug-induced death was $48(24.12 \%)$. Followed by an emergency visit was $43(21.4 \%)$, the hospital admission was $46(23.1 \%)$, critical care admission was $24(12.1 \%)$, and general surgery $24(11.9 \%)$ as explored in Table 2 . The most frequent drug-related problems occurred with the patient last year at least once; it was drug noncompliance $142(71.4 \%)$, indications without medication $100(50 \%)$, and adverse medication events 80 (40\%). There are no statistical differences in drug-related problems clinical outcomes between patients and healthcare professional $(\mathrm{p}>0.05)$. There is a statistical difference of a knowledge of what to do toward the problems (Medications errors, Drug poisoning, drug interaction, indication without medications) occurred between patients and healthcare professional $(\mathrm{p}<0.05)$ as explored in Table 3. The most drug-related problems lead to visit the doctor at ambulatory care clinic was the adverse drug reaction $44(22.2 \%)$ and drug non-compliance 29 $(14.65 \%)$, while the most problem leads to the laboratory requisition were drug poisoning $19(9.84 \%)$ and adverse drug reaction 17 (8.81\%). The most problem lead to pharmacy visit were adverse drug reaction $25(12.5 \%)$ and medications without indication $15(7.5 \%)$ and indication without medications $15(7.5 \%)$. The most problems induced the emergency visit or hospital admission or surgery were drug poisoning 28 (13.93\%) and medication errors $14(6.97 \%)$ while the problems induced hospital admission were drug poisoning $25(12.56 \%)$ and medication errors 19 (9.55\%). The most problems need surgery were drug poisoning $18(8.96 \%)$ and medication errors $13(6.47 \%)$. The most problem lead to critical care admission were drug poisoning $18(9.05 \%)$ and drug interaction 15 (7.54\%) while problems lead to death medications errors $21(10.55 \%)$ and drug poisoning $13(6.53 \%)$ as explored in Table 4.

\section{DISCUSSION}

The general administration of pharmaceutical care within strategic pharmacy plan Established several programs to prevent the complication of drugrelated problems. ${ }^{[14]}$ That has included medication safety program, pharmacist intervention, participated with therapeutic guidelines and protocols, participated with hotline call center with national drug information centers, and implementation of Saudi Center of healthcare organization with patient safety requirements. ${ }^{[15-18]}$ The investigator tried to investigate the Magnitude of the drug-related problem with healthcare professionals and patient perspectives. The finding of the study showed the complication and the sequence of outcomes of drug-related problems were ambulatory care visit because of it is straightforward to access by the patient especially the private clinic. Also, it very cheap with or without healthcare insurance coverage. The patients might visit the pharmacy if any of drug-related problems occurred with them. It was first one to contact the patient might prefer the ambulatory care clinic than the pharmacy that's may more trustworthy on the physician than the pharmacist and more gaining knowledge of drug-related problems. Moreover, maybe the patient visited the ambulatory care clinic for treatment or need any additional laboratory tests. The finding showed the second higher percentage of drug-related problems complications lead to death than an emergency visit or hospital admission or critical care admission. That has related the imperfect knowledge, and misusage of some medications or non-adherence of medications lead to disease complications and sequencing death. The finding showed there is no statistically significant difference between the patients and healthcare providers. That is maybe their practice as same as of both lifestyles behavior and perception toward the drug-related problems. The results of drug-related problems lead to emergency visit almost resemble what reported by $\mathrm{Al}-\mathrm{Arifi}, \mathrm{M}$ et al. and higher than what reported by Al-Olah, YH et al..$^{7,19]}$ While the hospital admission is resembled what reported by Nivya, $\mathrm{K}$ et al. but higher than what reported by Al-Arifi, $\mathrm{M}$ et al. that is due to increasing of percentage over the past several years, and patient perspective higher that what documented in the patient profile. ${ }^{[7,20]}$ The drug-related problems lead to critical admission percentages higher than what reported by Hammerman, H. et al. because out study more general not focused at one area of medicines, poor implementation of patient education programs at healthcare organizations, and reduced background on medications knowledge. ${ }^{[1]]}$ The most medications induced drug-related problems with all patient and healthcare professionals were antibiotics with a high rate of non-compliance and not completed the course of the therapy and prescribing or administration by healthcare professionals. Also, the painkillers and dermatology medications the second one that is due some patient taking medications for common pain like headaches or muscular pain or cosmetic medications. Those may induce adverse drug reaction. There are no statistically significant differences between patient and healthcare professionals with most of the medications induced drug-related problems except the anti-diabetic or Antihypertensive medications adverse drug reaction, medications errors, drug non-compliance and drug interaction. The healthcare professionals are higher than the patient. That has related the inadequate monitoring of drug-related problems of those medications after prescribing or overprescribing the medications. The adverse drug reaction or non-compliance most problems lead to ambulatory care visit. The most of study site patient refer to the physician if there are straightforward problems like previous problems. The most problems lead the pharmacy visit was adverse drug reaction or medications without indication and indication without medications. That has given us a good impression of the patient and required more information about drug therapy and drug-related problems. The drug poisoning and medication errors were the most problems lead to an emergency visit or hospital admission or perform surgery or death. That finding expected due to the dangers of the problem, and drug poisoning center is not fully working and provided the services to the patients. The clinical outcome of drug-related problems from patient or healthcare 
Alomi, et al.: Study about drug related problems among Saudi Patients

\begin{tabular}{|c|c|c|c|c|c|c|}
\hline Characterictics & $\begin{array}{l}\text { Patients } \\
\text { n (\%) }\end{array}$ & $\begin{array}{l}\text { Healthcare } \\
\text { Professional's } \\
\text { n (\%) }\end{array}$ & $\begin{array}{l}\text { Total } \\
\text { comparisons } \\
\text { n (\%) }\end{array}$ & $\begin{array}{l}\text { Total } \\
\text { Response } n\end{array}$ & $\begin{array}{l}\text { Total } \\
\text { Response \% }\end{array}$ & $P$ value \\
\hline \multicolumn{7}{|l|}{ Sex } \\
\hline Female & $138(89.03 \%)$ & $40(90.91 \%)$ & $178(89.45 \%)$ & 180 & $89.6 \%$ & $>0.05$ \\
\hline Male & $17(10.97 \%)$ & $4(9.09 \%)$ & $21(10.55 \%)$ & 21 & $10.4 \%$ & $>0.05$ \\
\hline Answered question & $155(77.89 \%)$ & $44(22.11 \%)$ & 199 & 201 & & \\
\hline Skipped question & & & 2 & 0 & & \\
\hline \multicolumn{7}{|l|}{ Nationality } \\
\hline $\begin{array}{l}\text { Saudi } \\
\end{array}$ & $151(97.42 \%)$ & $35(79.55 \%)$ & $186(93.47 \%)$ & 188 & $93.5 \%$ & $<0.05$ \\
\hline Non-Saudi & $4(2.58 \%)$ & $9(20.45 \%)$ & $13(6.53 \%)$ & 13 & $6.5 \%$ & $<0.05$ \\
\hline Answered question & $155(77.89 \%)$ & $44(22.11 \%)$ & 199 & 201 & & \\
\hline Skipped question & & & 2 & 0 & & \\
\hline \multicolumn{7}{|l|}{ Age } \\
\hline$<18$ & $1(0.65 \%)$ & $0(0.00 \%)$ & $1(0.50 \%)$ & 1 & $0.5 \%$ & $>0.05$ \\
\hline $18-29$ & $80(51.61 \%)$ & $33(75.00 \%)$ & $113(56.78 \%)$ & 113 & $56.2 \%$ & $<0.05$ \\
\hline $30-44$ & $53(34.19 \%)$ & $9(20.45 \%)$ & $62(31.16 \%)$ & 64 & $31.8 \%$ & $>0.05$ \\
\hline $45-59$ & $21(13.55 \%)$ & $2(4.55 \%)$ & $23(11.56 \%)$ & 23 & $11.4 \%$ & $>0.05$ \\
\hline $60+$ & $0(00.00 \%)$ & $0(00.00 \%)$ & $0(00.00 \%)$ & 0 & $0.0 \%$ & $>0.05$ \\
\hline Answered question & $155(77.89 \%)$ & $44(22.11 \%)$ & 199 & 201 & & \\
\hline Skipped question & & & 2 & 0 & & \\
\hline \multicolumn{7}{|l|}{ Healthcare providers } \\
\hline Yes & $0(00.00 \%)$ & $44(100.0 \%)$ & $44(22.11 \%)$ & 44 & $22.1 \%$ & $<0.05$ \\
\hline Non & $155(100.0 \%)$ & $0(00.00 \%)$ & $155(77.89 \%)$ & 155 & $77.9 \%$ & $<0.05$ \\
\hline Answered question & $155(77.89 \%)$ & $44(22.11 \%)$ & 199 & 199 & & \\
\hline Skipped question & & & 2 & 2 & & \\
\hline Type of healthcare professional & & & & Response Count & Response Percent & \\
\hline Physician & & & & 3 & $5.77 \%$ & \\
\hline Dentist & & & & 4 & $7.69 \%$ & \\
\hline Pharmacist & & & & 34 & $65.38 \%$ & \\
\hline Nurse & & & & 6 & $11.54 \%$ & \\
\hline Others & & & & 5 & $9.62 \%$ & \\
\hline Answered question & & & & 52 & & \\
\hline Skipped question & & & & 0 & & \\
\hline Academic Qualifications & & & & Response Count & Response Percent & \\
\hline Doctorate degree & $4(2.58 \%)$ & $3(6.82 \%)$ & $7(3.52 \%)$ & 7 & $3.5 \%$ & $>0.05$ \\
\hline Master degree & $15(9.68 \%)$ & $2(4.55 \%)$ & $17(8.54 \%)$ & 18 & $9.0 \%$ & $>0.05$ \\
\hline Bachelor Degree & $104(67.10 \%)$ & $32(72.73 \%)$ & $136(68.34 \%)$ & 137 & $68.2 \%$ & $>0.05$ \\
\hline Diploma & $3(1.94 \%)$ & $3(6.82 \%)$ & $6(3.02 \%)$ & 6 & $3.0 \%$ & $>0.05$ \\
\hline High school & $26(16.77 \%)$ & $4(9.09 \%)$ & $30(15.08 \%)$ & 30 & $14.9 \%$ & $>0.05$ \\
\hline Intermediate School & $1(0.65 \%)$ & $0(0.00 \%)$ & $1(0.50 \%)$ & 1 & $0.5 \%$ & $>0.05$ \\
\hline Primary School & $1(0.65 \%)$ & $0(0.00 \%)$ & $1(0.50 \%)$ & 1 & $0.5 \%$ & $>0.05$ \\
\hline Not educated & $1(0.65 \%)$ & $0(0.00 \%)$ & $1(0.50 \%)$ & 1 & $0.5 \%$ & $>0.05$ \\
\hline Answered question & $155(77.89 \%$ & $44(22.11 \%)$ & 199 & 201 & & \\
\hline Skipped question & & & 2 & 0 & & \\
\hline
\end{tabular}


Table 2: The extent of medications caused drug related problems

\begin{tabular}{|c|c|c|c|c|c|c|c|c|c|c|c|c|c|c|c|c|}
\hline $\begin{array}{l}\text { Answer } \\
\text { Options }\end{array}$ & 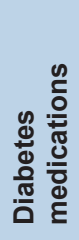 & 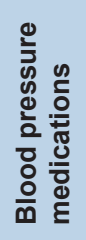 & 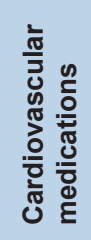 & 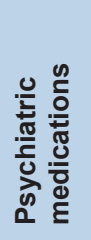 & 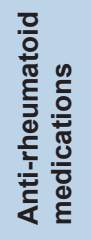 & 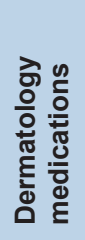 & 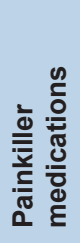 & 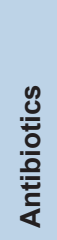 & $\begin{array}{l}\frac{0}{0} \\
\frac{2}{2} \\
\frac{0}{0} \\
\frac{\pi}{c} \\
\frac{0}{0}\end{array}$ & 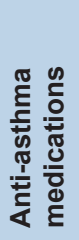 & 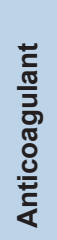 & 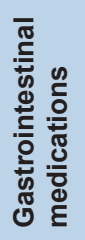 & 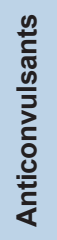 & $\begin{array}{l}\frac{n}{d} \\
\frac{\mathscr{g}}{\tilde{t}}\end{array}$ & 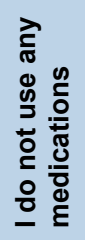 & 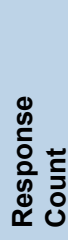 \\
\hline $\begin{array}{l}\text { Medication adverse } \\
\text { reaction* }\end{array}$ & 8 & 4 & 0 & 6 & 4 & 31 & 20 & 38 & 11 & 4 & 0 & 12 & 3 & 31 & 85 & 197 \\
\hline Medication errors ${ }^{*}$ & 2 & 3 & 3 & 0 & 3 & 11 & 4 & 15 & 4 & 2 & 1 & 5 & 0 & 16 & 142 & 190 \\
\hline Drug poisoning & 2 & 1 & 1 & 0 & 2 & 0 & 2 & 4 & 0 & 1 & 3 & 4 & 2 & 6 & 169 & 190 \\
\hline Drug noncompliance* & 5 & 2 & 1 & 5 & 1 & 26 & 21 & 43 & 14 & 6 & 0 & 18 & 0 & 29 & 76 & 197 \\
\hline $\begin{array}{l}\text { Medication without } \\
\text { indications }\end{array}$ & 4 & 0 & 1 & 2 & 3 & 5 & 24 & 15 & 10 & 3 & 0 & 7 & 0 & 15 & 128 & 192 \\
\hline Drug interactions ${ }^{*}$ & 4 & 1 & 0 & 0 & 5 & 13 & 27 & 23 & 9 & 1 & 0 & 14 & 0 & 25 & 110 & 194 \\
\hline $\begin{array}{l}\text { Indications without } \\
\text { medication }\end{array}$ & 4 & 2 & 2 & 1 & 0 & 2 & 6 & 12 & 1 & 4 & 1 & 4 & 0 & 7 & 162 & 195 \\
\hline Total & 29 & 13 & 8 & 14 & 18 & 88 & 104 & 150 & 49 & 21 & 5 & 64 & 5 & 129 & 872 & \\
\hline \multicolumn{16}{|l|}{ answered question } & 201 \\
\hline skipped question & & & & & & & & & & & & & & & & 0 \\
\hline
\end{tabular}

*There is higher statistically differences of type of medications Antidiabetics, Antihypertension problems (Adverse drug reaction, Medications errors, Drug noncompliance, drug interaction) occurred between healthcare professionals and patients $(p<0.05)$

\begin{tabular}{|c|c|c|c|c|c|c|c|c|c|c|c|c|}
\hline Answer Options & 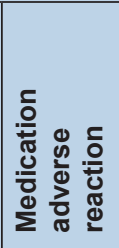 & 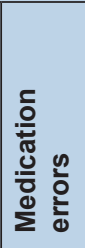 & 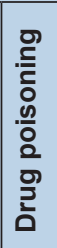 & 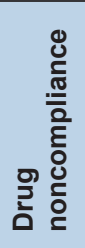 & 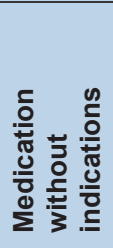 & 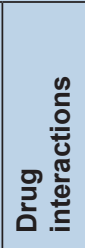 & 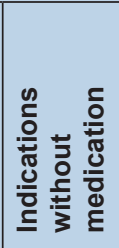 & $\sum_{\bar{z}}^{\bar{\Xi}}$ & 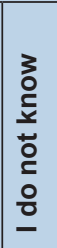 & 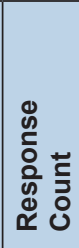 & 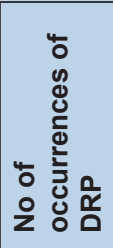 & 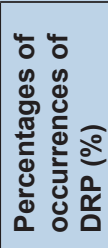 \\
\hline $\begin{array}{l}\text { Which of drug related } \\
\text { problems have you ever } \\
\text { experienced? }\end{array}$ & 59 & 9 & 6 & 60 & 15 & 5 & 23 & 54 & 36 & 199 & 109 & 54.77 \\
\hline $\begin{array}{l}\text { Which of drug-related } \\
\text { problems you know what } \\
\text { to do toward the problems } \\
\text { occur? \# }\end{array}$ & 67 & 15 & 24 & 46 & 28 & 15 & 26 & 43 & 53 & 196 & 100 & 51.02 \\
\hline $\begin{array}{l}\text { Which of drug related } \\
\text { problems lead you to visit a } \\
\text { doctor at a clinic?* }\end{array}$ & 44 & 15 & 14 & 29 & 9 & 13 & 7 & 93 & 29 & 198 & 76 & 38.38 \\
\hline $\begin{array}{l}\text { Which of drug related } \\
\text { problems lead you to make } \\
\text { laboratory and non-laboratory } \\
\text { tests?* }\end{array}$ & 17 & 12 & 19 & 7 & 3 & 12 & 5 & 112 & 34 & 193 & 47 & 24.35 \\
\hline $\begin{array}{l}\text { Which of drug related } \\
\text { problems lead you to visit the } \\
\text { pharmacy?* }\end{array}$ & 25 & 9 & 2 & 13 & 15 & 4 & 15 & 107 & 34 & 200 & 59 & 29.50 \\
\hline $\begin{array}{l}\text { Which of drug related } \\
\text { problems lead you to } \\
\text { Emergency department?* }\end{array}$ & 12 & 14 & 28 & 1 & 2 & 11 & 1 & 133 & 25 & 201 & 43 & 21.39 \\
\hline $\begin{array}{l}\text { Which of drug related } \\
\text { problems lead you to a } \\
\text { hospital admission?* }\end{array}$ & 13 & 19 & 25 & 10 & 4 & 9 & 4 & 130 & 23 & 199 & 46 & 23.12 \\
\hline $\begin{array}{l}\text { Which of drug related } \\
\text { problems lead you to do } \\
\text { surgery? }\end{array}$ & 3 & 13 & 18 & 4 & 3 & 9 & 2 & 151 & 26 & 201 & 24 & 11.94 \\
\hline $\begin{array}{l}\text { Which of drug related } \\
\text { problems lead you } \\
\text { to intensive care unit } \\
\text { admission*? }\end{array}$ & 9 & 12 & 18 & 4 & 5 & 15 & 1 & 150 & 25 & 199 & 24 & 12.06 \\
\hline $\begin{array}{l}\text { Which of drug-related } \\
\text { problems induced death to a } \\
\text { family member or friend*? }\end{array}$ & 9 & 21 & 13 & 11 & 4 & 8 & 5 & 104 & 47 & 199 & 48 & 24.12 \\
\hline $\begin{array}{l}\text { Which of drug related } \\
\text { problems management covers } \\
\text { by health insurance? }\end{array}$ & 18 & 16 & 12 & 8 & 5 & 8 & 7 & 80 & 91 & 200 & 29 & 14.50 \\
\hline \multicolumn{10}{|l|}{ answered question } & 201 & & \\
\hline \multicolumn{10}{|l|}{ skipped question } & 0 & & \\
\hline
\end{tabular}

*There is no statistical differences in drug-related problems clinical outcomes between patients and healthcare professional $(p>0.05)$

\# There is statistically differences of a knowledge of what to do toward the problems (Medications errors, Drug poisoning, drug interaction, indication without medications) occurred between patients and healthcare professional $(p<0.05)$ 
Alomi, et al:: Study about drug related problems among Saudi Patients

\begin{tabular}{|c|c|c|c|c|c|c|c|c|c|}
\hline & łunoว әsuodsəy & $\stackrel{\circ}{\circ}$ & $\stackrel{\Re}{\stackrel{2}{2}}$ & ঃํ & $\bar{\Sigma}$ & $\stackrel{\text { \& }}{\circ}$ & $\overline{\text { న }}$ & g & $\stackrel{\circ}{\circ}$ \\
\hline & (\%) sәбеұuәэ.д्d & 离 & 各 & 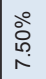 & 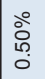 & $\stackrel{\circ}{\grave{c}}$ & @ั & 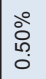 & 윰 \\
\hline & 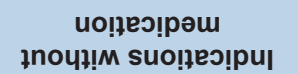 & n & \llcorner & $\stackrel{2}{\sim}$ & - & $\checkmark$ & $\sim$ & - & ڤ \\
\hline & (\%) sәбеұuәวдәd & 音 & సิํำ & ○ें & 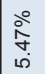 & 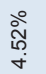 & 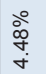 & 啇 & ڤે̀ \\
\hline & suo!ฺәеләұц! 6nגa & $\stackrel{m}{\underline{m}}$ & $\cong$ & $\nabla$ & $\mp$ & $\sigma$ & $a$ & $\stackrel{\llcorner}{\leftarrow}$ & $\infty$ \\
\hline & (\%) sәбеұuәэдәd & 宽 & 悹 & 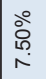 & 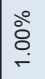 & $\stackrel{\circ}{\grave{c}}$ & 亭 & $\stackrel{\circ}{\circ}$ & ؛ें \\
\hline & 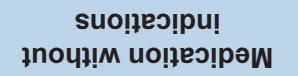 & $\sigma$ & $m$ & $\stackrel{\llcorner}{\leftarrow}$ & $N$ & $\nabla$ & $m$ & in & $\nabla$ \\
\hline & (\%) sәбеұuәэдәd & 宽 & 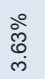 & 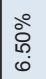 & 容 & 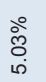 & ஓे & 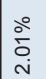 & 命 \\
\hline & פנג & $\stackrel{2}{N}$ & $\wedge$ & $m$ & - & 운 & $\nabla$ & $\sigma$ & $=$ \\
\hline & (\%) sә6еұuәગ.д्d & 竞 & 高 & 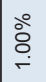 & 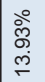 & $\begin{array}{l}\stackrel{\circ}{\circ} \\
\stackrel{0}{0}\end{array}$ & $\begin{array}{l}\stackrel{\circ}{\circ} \\
\infty \\
\infty\end{array}$ & $\begin{array}{l}\stackrel{\circ}{\circ} \\
\text { ஸे }\end{array}$ & 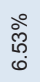 \\
\hline & Gu!uos!̣od 6nua & 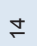 & $\stackrel{9}{\leftarrow}$ & $N$ & $\stackrel{\infty}{N}$ & $\stackrel{\sim}{N}$ & $\stackrel{\infty}{\sim}$ & $\stackrel{\infty}{\sim}$ & $\stackrel{m}{-}$ \\
\hline & (\%) sәбеұuәэ.ر्d & $\stackrel{\circ}{\stackrel{\circ}{\circ}}$ & $\underset{\text { సิ }}{\stackrel{0}{0}}$ & $\stackrel{\circ}{\circ}$ & 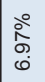 & 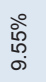 & $\begin{array}{c}\stackrel{\circ}{\hat{े}} \\
\stackrel{5}{0}\end{array}$ & $\begin{array}{l}\stackrel{\circ}{0} \\
\text { Oे } \\
\dot{0}\end{array}$ & $\begin{array}{l}\stackrel{\circ}{\circ} \\
\stackrel{0}{0} \\
\stackrel{0}{\circ}\end{array}$ \\
\hline & sıодมә ио!ןеэ!рәW & $\stackrel{2}{\sim}$ & $\cong$ & a & 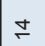 & $\stackrel{2}{\leftarrow}$ & $\stackrel{m}{\sim}$ & $\stackrel{\sim}{\simeq}$ & $\bar{N}$ \\
\hline 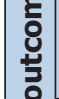 & (\%) sәбеұuәэдәd & ڤે & $\underset{\substack{\circ \\
\infty \\
\infty \\
\infty}}{\infty}$ & 突 & $\begin{array}{l}\stackrel{0}{2} \\
\vdots \\
0 \\
i\end{array}$ & 仓̊ํำ & $\stackrel{\circ}{\stackrel{\circ}{\circ}}$ & 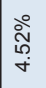 & $\underset{\substack{0 \\
\text { ஸे }}}{+}$ \\
\hline 름 & 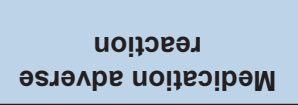 & $z$ & 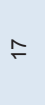 & $\stackrel{2}{N}$ & $\cong$ & $\stackrel{m}{\longrightarrow}$ & $m$ & o & 0 \\
\hline 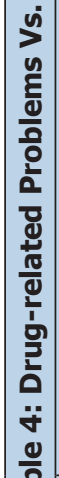 & 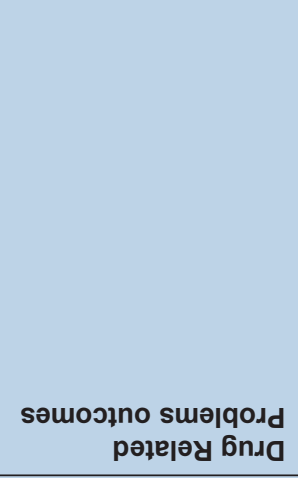 & 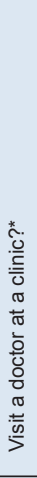 & 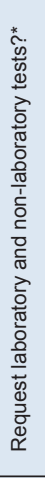 & 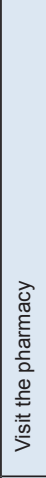 & 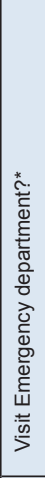 & 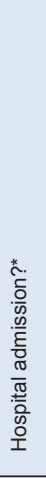 & 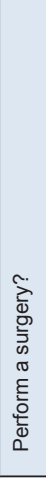 & 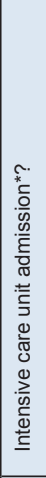 & 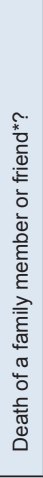 \\
\hline & ON & - & $\sim$ & $m$ & $\nabla$ & ڤ & 0 & $\wedge$ & $\infty$ \\
\hline
\end{tabular}

perception reflected the reality of drug-related problems. That needs very comprehensive effort to prevent the problems in the future and involved the significant role of the pharmacist in preventing them. Most of the results could not compare with other studies due to hard to find studies discussed the complications of drug-related problems at one publication and maybe the first investigation about this issues.

\section{CONCLUSION}

The complication of drug-related problems with patient and healthcare professionals perception is the almost the same what has investigated previously. Drug-related problems monitoring with public education is necessary at Ministry of Health hospitals in Kingdom of Saudi Arabia.

\section{ACKNOWLEDGMENT}

None.

\section{CONFLICT OF INTEREST}

None

\section{ABBREVIATIONS}

KSA: Kingdom of Saudi Arabia; ASHP: American Society of HealthSystem Pharmacist; MOH: Ministry of Health; USA: United States of America.

\section{REFERENCES}

1. ASHP. ASHP Statement on Pharmaceutical Care. Am J Hosp Pharm. 1993;50:1720-3.

2. American Society of Health-System Pharmacists. ASHP guidelines on a standardized method for pharmaceutical care. American Society of HealthSystem Pharmacists. Am J Heal Pharm. 1996;53(14):1713-6.

3. Ramalho de Oliveira D, Brummel AR, Miller DB. Medication therapy management: 10 years of experience in a large integrated health care system. J Manag Care Pharm. 2010;16(3):185-95.

4. Van den Bemt PM, Van den Bemt PM, Egberts TC, Egberts TC, De Jongvan den Berg LT, De Jong-van den Berg LT, et al. Drug-related problems in hospitalized patients. Drug Saf. 2000;22(4):321-33.

5. Viswanathan M, Kahwati LC, Golin CE, Blalock SJ, Coker-Schwimmer E, Posey R, et al. Medication Therapy Management Interventions in Outpatient Settings. Comparative Effectiveness Review No. 138. AHRQ Publication No. 14(15)-EHC037-EF. 2015;175(1):76-87.

6. Bootman J, Johnson JA. Drug-related morbidity and mortality: A cost-of-illness model. Arch Intern Med. 1995;155(18):1949-56.

7. Al-Arifi M, Abu-Hashem $\mathrm{H}$, Al-Meziny M, Said R, Aljadhey $\mathrm{H}$. Emergency department visits and admissions due to drug-related problems at Riyadh military hospital (RMH), Saudi Arabia. Saudi Pharm J. 2014;22(1):17-25.

8. Middleton J, McGrail S, Stringer K. Drug-related deaths in England and Wales. BMJ. 2016;355:i5259.

9. Al-Azzam SI, Alzoubi KH, Aburuz S, Alefan Q. Drug-related problems in a sample of outpatients with chronic diseases: A cross-sectional study from Jordan. Ther Clin Risk Manag. 2016;12:233-9.

10. Rashed AN, Wilton L, Lo CC, Kwong BY, Leung S, Wong IC. Epidemiology and potential risk factors for drug-related problems in Hong Kong pediatric wards. Br J Clin Pharmacol. 2014;77(5):873-9.

11. Hammerman $\mathrm{H}$, Kapeliovich $\mathbf{M}$. Drug-related cardiac iatrogenic illness as the cause for admission to the intensive cardiac care unit. Isr Med Assoc J. 2000;2(8):577-9.

12. Strand LM, Morley PC, Cipolle RJ, Ramsey R, Lamsam GD. Drug-related problems: Their structure and function. Ann Pharmacother. 1990;24(11):1093-7.

13. Pk A, Adepu R. Drug-related problems: an overview of various classification systems. Asian J Pharm Clin Res. 2014;7(4):7-10.

14. Alomi YA, Alghamdi SJ, Alattyh RA. Strategic Plan of General Administration of Pharmaceutical Care at Ministry of Health in Saudi Arabia 2012-2022. J Pharm Pharm Scien. 2015;1(3):1-8. 
Alomi, et al:: Study about drug related problems among Saudi Patients

15. Alomi YA. National Medication Safety Program at Ministry of Health in Saudi Arabia. J Pharmacovigi. 2015;3(5):1-2.

16. Al-Hameed FM, Al-Dorzi HM, Abdelaal MA, Alaklabi A, Bakhsh E, Alomi YA, et al. The Saudi clinical practice guideline for the prophylaxis of venous thromboembolism in medical and critically ill patients. Saudi Med J. 2016;37(11):1279.

17. Alomi YA, Mudaiheem HA. National Drug Information Center Services through Ministry of Health Hotline Calling Center (937) in Saudi Arabia. Adv Pharmacoepidemiol Drug Saf. 2016;5(1).
18. Medication Management (MM). In: National Hospital Standards. 2nd Editio. Saudi Central Board for Accreditation of Healthcare Institutions. 2015:194-211. Available from: http://www.cbahi.gov.sa

19. Al-Olah $\mathrm{YH}$, Thiab KM Al. Admissions through the emergency department due to drug-related problems. Ann Saudi Med. 2008;28(6):426-9.

20. Nivya K, Sri Sai Kiran V, Ragoo N, Jayaprakash B, Sonal Sekhar M. Systemic review on drug-related hospital admissions - A PubMed based search. Saudi Pharmaceutical Journal. 2015;23(1):1-8.

Cite this article as: Alomi YA, Al-Shaibani AS, Alfaisal G, Alasmi NM. Clinical Outcomes of Drug-related Problems in Saudi Arabia: Patients' and Healthcare Providers' Perspective. J Pharm Pract Community Med. 2018;4(2):77-82. 